\title{
Revolution in Times of Eurosclerosis: The Case of the First Lomé Convention
}

\author{
Lotte Drieghe \& Jan Orbie
}

Jan Orbie is Professor at Ghent University Centre for EU Studies.

Lotte Drieghe is Research Assistant at Ghent University Centre for EU Studies.

\section{Introduction}

In the past five years the European Union (EU) seems to have suffered from Eurosclerosis again. The EU has increasingly been contested, as witnessed by the referenda on the Constitutional Treaty in France, the Netherlands and Ireland, and by the criticism against the EU's response to the financial and economic crisis. It seems that the 'permissive consensus' on the merits of the EU has ceased to exist and that the European integration project has reached the ceiling. However, despite the widespread malaise in the Union's internal affairs, its ambitions and initiatives on the international scene have grown considerably in recent years. The EU has played a leading role in the launching of a broad trade agenda under the World Trade Organization, it has successfully manifested itself as a climate leader in the post-Kyoto discussions, as a supporter of 'effective multilateralism' within the United Nations institutions, and as the world's largest aid donor. Through its enlargement and neighbourhood policies, the Union effectively manages to transform political and social structures of the countries in its 'near abroad'. A comprehensive European Security Strategy has been elaborated by the European Council and more than twenty civilian and military missions have been deployed in various parts of the world. 
A similar paradox can be noticed at the beginning of the 1970s. Then too, the European project seemed to be faltering in the face of an economic crisis. Instead of an aggregated approach at the EC level, all Member States of the Community choose the national path to avert the crisis. An atmosphere of 'Eurosclerosis' characterized the European political scene where supranational institutions were widely considered to be irrelevant. However, at the same time, the European Community started to develop a more global profile in the period 1970-73 (Orbie 2008, 7). ${ }^{1}$ At a conceptual level, it was argued that Europe's distinctive global role would not be based on traditional military power, but it would nevertheless be influential on the basis of its internal economic strength. Some idealistic thinkers imagined a 'civilian power Europe' that uses its economic leverage to disseminate the European model and values to the world (Duchêne 1972; 1973), while more critical scholars depicted the European Community as an 'imperialist' and 'capitalist superpower' that pursues old policies with new means (Galtung 1973).

European policy-makers also started thinking aloud about the European Community's position in world politics. In 1973 - the year of Henry Kissinger's 'Year of Europe' initiative - the nine European Ministers of Foreign Affairs formulated the 'Declaration on European Identity' in order to define the EC's relations with other countries and its position in world affairs. Following The Hague Summit in 1969, a mechanism of European Political Cooperation had been introduced. This involved a Europeanisation of the member states' foreign policies, although still very modest. For example, the EC member states managed to coordinate their activities within the Conference for Security and Cooperation in Europe that was launched in 1973. Also in 1973, the first enlargement with Ireland, Denmark and in particular the United Kingdom raised the Community's international profile. In 1974, the European Community was also the first non-state entity to acquire the status of observer within the General Assembly of the United Nations and a range of other UN programs, commissions and organizations. Moreover, the seventies showed increased European activities in international environmental policies, for example through its role in the UN Stockholm Conference on Human Environment (1972).

The European Community also manifested itself in the trade and development nexus. It negotiated as a single actor in the Tokyo Round of multilateral trade negotiations, while weaving a dense web of trade and cooperation agreements at the bilateral level. The first generation of cooperation agreements with the Southern and Eastern Mediterranean countries, signed in the 1970s, strengthened Europe's

1. Since the debacle of the European Defense Community in 1954, most European policy-makers had abandoned the idea of a stronger political Europe in the world. The subsequent European Economic Community (1957) would limit itself to economic integration at the internal level. 
clout towards the European neighbourhood. Moreover, its relations with the developing South were extended to Asia and Latin America with the establishment of a Generalized System of Preferences (GSP) granting unilateral trade preferences for these countries in 1971, and with a number of bilateral cooperation arrangements. But most importantly, the European Community negotiated the first Lomé Convention with the group of African, Caribbean and Pacific (ACP) countries between 1973 and 1975. This was arguably the most comprehensive and progressive trade and cooperation agreement that has ever been concluded between a group of Northern and Southern countries.

Therefore, we consider the first Lomé Agreement as an interesting case to explore the European Community's international pro-activeness in a context of Eurosclerosis. In the next section, we will illustrate why the EC-ACP arrangement has often been seen as a revolutionary achievement. Subsequently, we will analyze to what extent this was indeed the case, based on a study of secondary literature and on original empirical research in the records. This will allow us to formulate some concluding remarks on the apparent paradox between global Eurooptimism and internal Eurosclerosis.

\section{The revolutionary Lomé Convention}

One of the most important and substantial projects the EC engaged in, while its internal integration was kept hostage by the economic crisis, was the Lomé Convention: a comprehensive partnership agreement between the EC and former colonies of the EC Member States in Africa, the Caribbean and the Pacific. This agreement sought to provide a framework to structure the trade and aid relations between the EC and these ACP countries. When the negotiations towards the Lomé Convention were finished, the result turned out to be much more than just a standard trade agreement. It was called revolutionary, unique in history and a model other developed countries should follow in their relations with the developing world. ${ }^{2}$

François-Xavier Ortoli, the then President of the Council, called the conclusion of the Lomé agreement 'a major turning point in history of the international economic relations'. His colleague, the President of the European Commission, talked about 'an agreement unique in the world and in history'. The chairman of the ACP, Babacar Ba, used the words 'revolutionary agreement' and the major newspapers in the EC spoke of 'one of the European Community's greatest

\footnotetext{
2. Regardless of its extraordinary features, it should be noticed that the Convention also had a long-lasting impact. Although the Lomé II (1980), III (1985), IV (1990), and IVbis (1995) agreements involved some modifications, the Lomé I model would basically shape the EU-ACP for more than 30 years. The Cotonou Agreement (2000) was a more substantial break with the past, although some clear traces to Lomé I can still be found (see e.g. Holland 2002; Hurt 2003; Babarinde and Faber 2005).
} 
achievements' and 'a new style of relationship between Europe and the Third World that is based upon equality and respect for reciprocal interests'. (The Courier $1975,7,12,16,19)$

The reasons why the Lomé Convention was perceived as a revolutionary landmark in the EC policy towards the developing countries are fourfold. Firstly, it was an amazing accomplishment to bring together such a large and diverse group of countries in a single agreement. Secondly, also the number of issues included in the partnership went beyond the standard trade agreement. Thirdly, the content and nature of some of the provisions, particularly the trade arrangements and mechanisms to stabilize export earnings, contributed to the innovative character. Fourthly, Lomé would establish a partnership 'based on complete equality between partners'. Each of these features will be examined more closely to get a better understanding of how these aspects gave the Lomé Convention its unique image.

The first reason why Lomé I could be seen as a watershed in the EU relations with the developing world is its geographical reach. The partnership was joined by the EC, which consisted of nine industrialized countries and 46 developing countries, united in the artificially created ACP group. Both the size and the geographical diversity of the developing country grouping were remarkable. With 37 countries, the African continent was well represented. The Convention also included nine Caribbean countries and three islands in the Pacific. Together with the EC member States, 55 countries spread over four continents ranging from least developed to some of the richest in the world engaged in the far reaching Lomé partnership (Lister 1988, 60-61). ${ }^{3}$

Not only the number of participants, but also the issues covered by the agreement were numerous. Besides a trade chapter, the convention included a chapter on export earnings from commodities (see below), which sought to establish a mechanism to stabilize the export revenues from important commodities. Furthermore, a chapter on financial and technical cooperation set forth the principles and criteria that would direct the distribution of the aid budget. Chapters on industrial cooperation, establishment, services, payment and capital movement would boost the economic development of the ACP countries. In addition, through information sharing, technical and logistic support, the industrial sector would expand and product diversification would be stimulated. Regulation on services, capital movement and investment could encourage the Foreign Direct Investments in ACP countries. The Convention also provided for the establishment of several institutions that would seek to execute and implement what was agreed upon (Frey Wouters 1980, Grilli, 1993, p. 27). It is thus clear that the Lomé Convention dealt with a lot more topics than classic trade agreements.

3. In comparison, there were about 80 members of the GATT at the time. 
From this perspective, one could even question whether the European Commission's emphasis on trade-related, 'behind-the-border' issues in today's trade negotiations is really a new phenomenon. Already in the mid-seventies, regulatory issues on services, investments, capital movements etc. were incorporated in EC trade agreements. Langham's (2009) research shows that "the fusion of ethics to economics within 'deep' liberalisation agendas is nothing 'new' in the history of ACP-EU relations".

A third feature that added to the revolutionary status of the Lomé Convention was the unique nature of the trade regime that was installed. The philosophy behind the GATT rules, as well as the previous Yaoundé Conventions between the EC and African countries, was that in principle both parties should open their markets for each other. Reciprocal trade liberalization would increase their economic competitiveness. Instead, the Lomé Conventions established non-reciprocity. While the EC committed itself to opening up its market for products from the ACP countries, the latter had no obligations towards the EC: the ACP countries could freely choose the tariffs and duties they imposed on EC products. ${ }^{4}$ Article 7 of the Convention stipulated that

in view of their present development needs, the ACP States shall not be required [...] to assume [...] obligations corresponding to the commitments entered into by the Community in respect of imports of the products originating in the ACP states.'

The argument behind this provision was to give the ACP countries the possibility to protect their markets when their economies were not yet ready to compete with European exporters. Thanks to this non-reciprocal trade regime, ACP countries could enter the European market under more favourable conditions than their non ACP competitors. Although the EC kept its right to impose import tariffs and quotas on ACP products that were subject to the European Common Agriculture Policy, European market access for agricultural products was still more favourable for the ACP than for other developing countries (FreyWouters 1980, 46; Lister 1988, 76-77).

In addition to non-reciprocal trade, the Lomé trade regime also included more interventionist parts. Two mechanisms were set up to stabilize the export revenues from commodities that were of major importance for an ACP states' economy: STABEX and the commodity protocols. In many developing countries one or two primary commodities made up more than half of the Gross Domestic Product (GDP) and therefore had a major impact on their export earnings. However, world market prices of primary commodities were (and are still) volatile. The instability and unpredictability of these prices created huge uncertainties about the incomes farmers could generate. It goes without saying that such economic

4. Except for the obligations under the Most Favored Nations Principle. 
premises are detrimental to the economic development of a country, especially when you take into account that the vast majority of the population works in the agricultural sector. The fact that farmers cannot adjust their production and thus supply to the demand did not make things any easier. Farmers did not know whether they would earn enough to sustain their family; neither could they make the investment needed to maintain a competitive position on the world market since there was no certainty about future income. To counter this problem, the Lomé Convention established several mechanisms to stabilize the export revenues. STABEX (Stabilisation of Exports Earnings) provided for loans and grants for which the ACP governments could apply when a certain commodity fell below a reference point. If the prices of these commodities increased, the loans could be paid off. Products that qualified for this mechanism were amongst others cocoa, coffee, cotton, coconut and tea (Holland 2002, 36). The commodity protocols granted the ACP countries a set price for a fixed amount of a certain commodity, regardless of the world market price. Such commodity protocols were established for sugar, bananas and rum (Grilli 1993, 31).

Because of the provisions on non-reciprocity and market intervention, which departed from the GATT philosophy at the time, the Lomé regime could be considered an alternative trade regime which is inspired by the New International Economic Order (NIEO) rather than the dominant liberal paradigm. Lomé was widely seen as a specific example of what an NIEO would look like in practice (Pass 1982, 20); some called it a "mini-NIEO" (Hveem 1980, 88-89). According to Grilli $(1993,42)$, the European Community has accepted the 'more reasonable' NIEO demands with the Lomé Convention.

The fourth factor that gave Lomé its progressive name was probably the most distinctive feature of the Lomé Convention: a commitment to an equal partnership between Europe and the ACP (Holland 2002, 34). Previous relations between the EC and former colonies of the EC member states were largely based on a one-way policy: the EC outlined the main part of the trade and aid regime with little manoeuvring space left for the developing countries to change the conditions of the agreement. During the negotiations towards Lomé, however, both partners were seen as equal players with equal voices in the negotiations, irrespective of the difference in real economic, political and military power (Lister $1988,103) .^{5}$

\footnotetext{
5. The idea of a true partnership was also reflected in the structure of the institutions founded in the Lomé Convention. Although the new institutions were similar to the institutional design of the Yaoundé Convention, predecessor of the Lomé Convention, they were based on the EC's commitment to an equal partnership. The ACP-EC Council of Ministers, composed of representatives from the ACP states, the EC member states and the European Commission, gathered annually to oversee the general scope of the Convention. The Committee of ambassadors assisted the Council of Ministers. The Joint Consultative Assembly consisted of an equal number of EC and ACP parliamentarians and could suggest recommendations or resolutions to the Council of Ministers. These proposals had, however, no binding effect (Holland 2002, 35).
} 
The United Nations Conference on Trade and Development (UNCTAD), at which developing countries had called for an NIEO, played an important role in building the self-assurance of developing countries. But besides this psychological shift in power, also the real power of the developing countries had increased due to the commodity crisis that had developed in the first half of the seventies. Prices of commodities were mounting at incredible speed, with oil as the most prominent example. Since these commodities constitute the most important part of the developing country exports, their economic power was growing significantly (Brown 2002, 51; Grilli 1993, 23-27). The atmosphere during and the result of the Lomé negotiations mirrored these evolutions. The EC member states no longer saw the former colonies as their subordinate backyard, but treated the $\mathrm{ACP}$ as true partners with respect for their sovereignty. Although the impact of this evolution cannot be measured, it is clear that it influenced several aspects of the Lomé agreement. First and foremost, never before had the EC put such an emphasis on the equality between partners in a bilateral agreement. Numerous references in the text of the Lomé partnership point at the parity of the parties. Even in unofficial documents this shift is noticeable: while at the beginning of the seventies the French permanent representative in the EU referred to the former colonies as their 'clients' in his informal correspondence with the Ministry of Foreign Affairs, a few years later they are called ACP or 'Francophones'/'Anglophones' in these unofficial briefings. ${ }^{6}$

\section{Putting Lomé in perspective}

How did the EC succeed in concluding such an innovative and groundbreaking agreement with such a large group of countries while the economic crisis was paralyzing the whole European Integration process? To answer this question, we take a closer look at the historical and international context as well as the negotiating dynamics leading to the first Lomé Convention. ${ }^{7}$ This leads to two qualifications of the 'revolutionary Lomé' thesis: (1) Lomé I was to a large extent also the continuation of previous policies by France and the United Kingdom towards their former colonies, and (2) these two EC member states have largely shaped the content and nature of the agreement through intergovernmental bargaining.

\footnotetext{
6. In a telex from February 1973, a few months before the Lomé negotiations begun, Burin Des Roziers, French ambassador in the European Union, reports that "La négociation de 'Yaoundé III' sera plus difficile pour nous et pour les Britanniques si chacun cherche a défendre ses 'clients' au détriment de ceux de l'autre" (SGCI CEE, 14 February 1973). Reports written in the subsequent years never mention the patronizing term "clients" to refer to the Francophone or Commonwealth ACP countries. This seems to indicate that the change in attitude towards the developing countries was not only paying lip service to the changing international discourse, but a true change in the minds of the European political elite.

7. This analysis is partly based on research in the official EU archives, the Belgian Diplomatic archive, and some private collections. It forms part of a Ph.D. research project (2007-2011) by Lotte Drieghe on this topic.
} 
Needless to say, the Lomé agreement did not appear out of thin air. Its roots go back to the very beginning of the European integration project. In 1957, when the six founding countries of the European Economic Community were negotiating the Treaty of Rome, France demanded that a solution be included for the special relations it maintained with the colonies. These special relations provided for beneficial and reciprocal market access between the colonies and the motherland. France wanted to 'Europeanize' this arrangement when joining the EC. Securing preferential market access to the EC market for the colonies, and thus keeping its influence in these countries, became a conditio sine qua non for the French to sign the treaty. Chapter IV of the Treaty of Rome established this preferential market access, along with an aid component ${ }^{8}$ for these colonies (Grilli 1993, 7-8; Frey-Wouters 1980, 13). When large parts of Africa became independent at the beginning of the sixties, chapter IV of the Treaty of Rome was replaced by an association agreement: the Yaoundé Convention, with the reciprocal market access and the aid budget being the most important aspects of the agreement. This convention was renewed in 1969 for another five years. In 1972, when the United Kingdom negotiated the accession conditions to join the EC, it also demanded a solution for the special relationship the UK maintained with its colonies, including a beneficial market access for these commonwealth countries. ${ }^{9}$ The EC decided that the Commonwealth could join the association agreement between the EC and the former colonies of France. The Yaoundé II convention would expire in 1975, so after a transition period of three years former colonies of the UK and France could jointly negotiate the renewal of the Yaoundé Convention (Lister 1988, 61). No ambitious ideas about development, but rather historical relations and practical consideration brought together such a exceptionally large group of developing countries in one comprehensive partnership agreement.

Besides the large number of participating development countries, the historical bond between EC member states and their former colonies also explains why the Lomé Convention included the progressive trade regime featuring non-reciprocal market access and stabilization mechanisms for export revenues (Drieghe 2009). Although never applied on such a scale, the export stabilization schemes were not new. Before the founding of the EC, the French government had established a

8. A European Development Fund (EDF) was established, financed directly by the EC Member States through donations. 'The sharing of the burden of aid to associated countries and territories was [thus] also the inevitable result of political negotiations among members (Grilli 1993, 83).' Today, this intergovernmental setup is still the main instrument of the EC development cooperation with the ACP.

9. The Belgian ambassador Rothschild, who was stationed in London during the Lomé negotiation talks, reported to the Belgium Ministry of Foreign Affairs that "le gouvernement travailliste [the British government] sétait engagé à resserrer les liens du Commonwealth et à s'efforcer que les pays members de cet organisme jouissent pour leurs exportations d'un accès maximum au marché commun." (Archives diplomatiques belges, 14 May 1974) 
mechanism to stabilize the export revenues of its colonies: products from overseas territories were exempted from quota and tariff restrictions and some products were granted a fixed price on the French market, higher than the world market prices. (Dodoo and Kuster 1977, 17). The UK had also set up a mechanism to stabilize the export earnings of a commodity that played a key role in many commonwealth economies: sugar. In the Commonwealth Sugar Agreement, the UK agreed to pay a fixed price for sugar from the Commonwealth countries, regardless of the world market price, until a quota was reached (Dickson and Ndhlovu 2002, 26). During the accession negotiations between the EC, the UK, Ireland and Denmark, the British negotiators asked for an arrangement between the EC and the Commonwealth that would replace their sugar agreement, since the UK could no longer determine its own market access conditions. After the transition period of three year during which the UK was permitted to keep up its bilateral trade arrangement with The Commonwealth, a new sugar regime was put forth in the Lomé Convention: the sugar protocol. However, since the sugar protocol would mostly benefit the Commonwealth countries, France demanded that a similar system be set up for commodities imported mainly by Francophone colonies.

'Ils [the Francophone ACP countries] considèrent quills feraient un marché de dupes en se prêtant à un règlement prématuré de la question de sucre. Ils considéreraient en fait comme un abandon de notre part [the French delegation] de nous prêter à un accommodement sur le sucre, dut-il être favourable à nos producteurs, sans le lier expressément à un accord d'ensemble sur les produits de base. Les arachides sont aussi importantes pour Sénégal que le sucre pour la Jamaïque, mont-ils dit. ${ }^{\prime 10}$

The other EC member states where not prepared to extend these interventionist commodity protocols to other products besides sugar, rum and bananas, partly because of the costs these systems entailed. Instead, the less far-reaching STABEX system was put into place. As noted above, this mechanism did affect the market price, but provided for loans and grants ACP countries could apply for when the world price for certain commodities fell below a reference point.

In an unofficial statement, the UK ambassador M.R. James makes it crystal clear that negotiations on export stabilization mechanisms were nothing but intergovernmental horse trading: 'Our final agreement on any scheme for other commodities will depend on the satisfactory arrangements being made for sugar.' ${ }^{11}$ And while the commodity scheme should be 'modest and have a financial ceiling', 'the arrangement for Commonwealth sugar should provide [...] ac-

10. SGCI CEE, 2 July 1974.

11. Archives diplomatiques belges, 20 June 1974. 
cess [to the European market] on fair terms for at least 1.4 million tons of sugar from the developing Commonwealth from 1975 onwards.' ${ }^{12}$

The introduction of non-reciprocal trade relations also resulted from intergovernmental bargaining between the EC Member States. France, which was supported by Germany ${ }^{13}$, Belgium, Italy, Luxemburg and the Commission, demanded a reciprocal trade regime, through the creation of a Free Trade Area. The French government feared that the introduction of non-reciprocal and preferential market access would destabilize relations with their former colonies, because this would violate the multilateral trade rules of the GATT. This violation would in turn make the EC vulnerable to contestation within the GATT. ${ }^{14}$ Another explanation for the French position is the fact that requesting a non-reciprocal trade system would weaken the bargaining position of the Francophone developing countries, the French delegation's allies in the Lomé negotiations. Unlike the Commonwealth countries, the EAMA (Etats africains et Madagascar associés) already traded with the EC under a reciprocal trade regime which gave them a superior starting position in the negotiations. Abandoning this reciprocity would take away this advantage for two reasons. Firstly, the Francophone ACP countries would have to change their trade policy towards the EC, while the Commonwealth could simply keep theirs. Secondly, choosing a non-reciprocal market access would mean that the EAMA countries would ask the EC a beneficial market access, while offering nothing in return. In other words, they would become the requesting party in the trade bargaining, depending on the good will of the EC to get their preferred trade regime. The EAMA acknowledged these problems and supported France in its plea for a reciprocal trade regime. ${ }^{15}$ Besides, France also wanted to preserve its beneficial access to some relatively important EAMA markets. However, these economic considerations were of minor importance: once it

12. Archives diplomatiques belges, 20 June 1974.

13. In the course of the negotiations, Germany changed its view on the reciprocity debate and sided with the UK, supporting the establishment of a non reciprocal trade regime.

14. The following citations from communication between the French foreign affairs ministry and the Coreper representative point out that the stability of the trade regime is of major importance for France:

"La réciprocité, c'est le Problème de fond le plus important. S'il n’y pas zone de libre-échange, au moins en principe, donc réciprocité, on ne voit pas ce qui fonderait les relations privilégiées avec les pays concernés. La porte serait ouverte au mondialisme. " (S.G.C.I. CEE, 1973)

"Il s'agissait de se mettre d'accord sur un régime des échanges qui soit contractuel, et par conséquence inattaquable sur le plan juridique. Or la Commission, dans son mémorandum d'avril 1973 (le "mémorandum Deniau ") avait exposé que seul le régime de la zone du libre-échange répondait à ces conditions. "

"Les délégations les plus attachées à la stabilité du régime des échanges à la spécificité de l'association, [sont] les délégations belge, italienne et française ». (SGCI CEE, 8 July 1974)

15. A quote in a communication of the French EC representative, Burin Des Roziers, to the French Ministry indicates that the Francophone ACP states did not support the official position of the ACP group, but preferred a simple renewal of the Yaoundé Convention: 'Ils [les AASM) n'attachent guère d'importance aux déclarations qu'ils ont laissé prononcer par les Anglophones au nom des ACP. Ce que souhaitent les Francophones, d'après M. Coulibaly, ambassadeur de la côte d'ivoire, c'est le renouvellement de la Convention de Yaoundé.' (SGCI CEE, July 2, 1974) 
became clear that the maintenance of the reciprocal trade regime would not be a walk-over, the French government dropped their demand for a de facto reciprocal market access. Instead, they pleaded for an Free Trade Area in theory for the sake of stable trade relations, but without the inclusion of any obligations towards the ACP concerning their market access.

The UK, on the other hand, followed by Ireland, the Netherlands and the Commonwealth pleaded for a non-reciprocal trade regime. Unlike the relationship between France and its colonies, the UK's relationship with the Commonwealth was based on a less rigid structure, recognizing state sovereignty as a core principle. Unilateral and non-reciprocal trade relations would give more flexibility to outline trade arrangements according to specific needs and wishes, without any restrictions created by the establishment of a free trade agreement. The following paragraph from a report of M.R. James, UK ambassador, on the Lomé negotiations describes the viewpoint of the UK delegation on reciprocity:

As Mr. Callaghan said in Luxembourg on 4 June, it is important that the Community should respect the developing countries' wish to avoid trade reciprocity. There must be no obligations on associates to provide the Community with tariff preferences in return for the preferences they enjoy in the Community market. ${ }^{16}$

Besides, non-reciprocity would diminish the bargaining power of the experienced associates, the Francophone states, in favour of the newcomers, the Commonwealth countries: whereas the former colonies of France already traded with the EC on a reciprocal basis under Yaoundé, the Commonwealth would be obliged to adjust their market access. Establishing a unilateral and non-reciprocal trade regime would take away the advantage of the Francophone developing countries and place the two groups on a more equal footing. ${ }^{17}$

This debate almost reached an impasse in negotiation, but a few days before the Kingston ACP EC ministerial conference took place in July 1974, the issue was settled when France, Belgium and Italy gave in on one condition: the trade regime should have a contractual basis, so that it would have a secure footing which could not be altered as easily as a unilateral Council decision on market access.

\footnotetext{
16. Archives diplomatiques belges, 20 June 1974.

17. The French Ambassador in the Coreper explains why the UK pleads for non-reciprocal market access: 'Les EAMA [former Yaoundé countries] partent dans cette négociation avec deux atouts qui les mettent dans une meilleure position que leurs homologues du Commonwealth : d'une part, ce sont les 'associés de la première heure' et le traite d'adhésion lui-même leur garantit le maintien de leur 'acquis', en termes suffisamment précis pour être efficaces. D'autre part, les EAMA donnent à la communauté des préférences inverses [i.e. reciprocal trade], et ne sont donc pas de simples quémandeurs : ils ont donc, sur ce point une position de départ plus forte que ceux qui voudraient donner le moins possible tout en prétendant obtenir autant qu'eux. Il est des ces conditions, assez naturel de la part des Britanniques de chercher à diminuer ces avantages dont bénéficient les EAMA dans la négociation' (SGCI CEE, 14 February 1973).
} 
In summary, the 'revolutionary' nature of the first Lomé agreement should be put into perspective. Firstly, the Lomé Convention was less innovative than sometimes assumed. A closer look at the historical precedents shows that it rather continues the member states' previous bilateral relations at the European level. Secondly, Lomé I was the result of intergovernmental bargaining between the EC member states, in particular France and the United Kingdom. In contrast, the European Commission has not played an autonomous role: it followed these member states' preferences rather than pursuing an external policy agenda on its own. Despite its putative 'commodity power', the influence of the ACP group was also limited; or more precisely: the interests of the African and Commonwealth ACPs were defended within the EC by their 'patrons' France and the United Kingdom, respectively. ${ }^{18}$

\section{Conclusions}

The first Lomé Convention between the EC and the ACP has often been hailed as a groundbreaking change in North-South relations. With hindsight it might indeed have been the most generous and innovative trade/aid arrangement ever offered by a group of developed countries. ${ }^{19}$ This article has highlighted the specific features of Lomé I: its geographical diversity, its comprehensive scope, the unique nature of the trade regime, and the partnership principle. However, we have also shown that many of the so-called new elements are less revolutionary than they appear at first sight. Provisions on non-reciprocal market opening, export stabilization schemes, and commodity protocols already existed before the agreement was negotiated. While the Treaty of Rome entailed the Europeanization of the preferential trade relations of France, the first Lomé Convention constituted a European compromise between French and British trade arrangements with their former colonies.

However, the Europeanization that took place through this comprehensive trade and aid arrangement was the result of pre-existing systems, and mainly driven by France and the United Kingdom. Two observations confirm an Intergovernmentalist reading of European integration in the 1970s: firstly, the two member states, France and the UK, basically shaped the Lomé I agreement in accordance with their economic and geopolitical preferences. Secondly, the European Commission only facilitated the negotiation process and did not pursue

18. Interestingly, Ravenhill (1985, 36-37) characterized Lomé as a 'collective client - patron' relationship between the ACP and the EC.

19. The most progressive elements of Lomé I had been eroded through the subsequent Lomé Conventions, and abandoned with the Cotonou Convention. The EU's current trade arrangements with the ACP group - consisting of Economic Partnership Agreements and the 'Everything But Arms' initiative - are less innovative and more in line with the rules of the World Trade Organization (see Arts and Dickson 2004; Orbie 2007). 
an agenda on its own. Our main thesis that Lomé I was not a novel project of the European Community, but rather a continuation of the largest member state's policies on a European scale, seems to be in line with the atmosphere of Eurosclerosis in the 1970s. After all, member state preferences are in the driving seat, determining the content and nature of policies at the European level.

Of course, these findings also resolve the observed paradox between internal Eurosclerosis and international proactiveness. Our interpretation of the first Lomé Convention as the Europeanization of French and British trade arrangements with former colonies, which also qualifies the role of the European Community as well as the ACP countries, confirms Intergovernmentalist interpretations of the European project in the 1970s. However, it should be emphasized that the establishment of the first Lomé Convention may have started a path-dependent process whereby the European Community has gradually assumed a more important role, for example through its role in the implementation of the agreement, and the management of STABEX and the commodity protocols. The European Commission has arguably played a more important role in the subsequent Lomé Conventions and in the recent Cotonou Agreement, which has led to Economic Partnership Agreements between the EU and ACP countries. Since the Lomé I Convention, the European Community has acquired a competence to deal with trade-aid arrangements towards the ACP (although its 'development-friendliness' is not less contested than in the 1970s).

Finally, it should be noticed that the revolutionary presentation of the first Lomé Convention can be linked to the legitimacy crisis inside the EU. As noted by the Council, "Le succès de Kingston [an EC-ACP ministerial meeting] est également un élément très important à un moment où la communauté cherche à raffermir sa cohésion à l'intérieur et à s'affirmer davantage à l'extérieur." ${ }^{20}$ International ambitions also serve as a means to establish cohesion inside the European Community. This hypothesis could also shed light on the European Union's current ambitions on various fronts, again in times of Eurosclerosis.

\section{BIBLIOGRAPHY}

\section{Selection of records}

X, X, Burin Des Roziers, 1973, S.G.C.I. C.E.E.

Relations avec les pays méditerranéens et avec les pays associes ou associables d'Afrique: problème des préférences inverses, Burin des Roziers, 14/02/1973, SGCI CEE

L'Afrique Francophone et la négociation CEE-ACP, Burin Des Roziers, 2/07/1974, SGCI CEE

Négociations C.E.E.-A.C.P, Burin Des Roziers, 8/07/1974, SGCI CEE

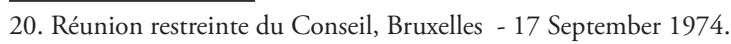


Négociations ACP, Robert Rothschild, 14/05/1974, Archives diplomatiques Belges.

Protocol 22, M.R. James, 20/06/1974, Archives diplomatiques belges.

Réunion Restreinte du conseil, Bruxelles, 17/09/1974, Emile Noël archives

\section{References}

ACP-EC Convention of Lomé, Lomé, 28 February 1975, OJ L 25, 30 January 1976, p. 2

ACP-EC Convention of Lomé, signed at Lomé on 28 February 1975, The Courier, Special Issue, March 1975, no. 31, 84 p.

Arts, K. and Dickson, A.K. (eds) (2004), EU Development Cooperation: From Model to Symbol?, Manchester, Manchester University Press.

Brown, W, (2002), The European Union and Africa, Restructuring of North-South Relations, London, Tauris \& Co Ltd.

Dickson, A. and Ndhlovu, T. , (2002), 'The sugar Protocol', p. 114-154, in Dearden, Stephen J. H., 'The European Union and the Commonwealth Caribbean', Alderschot, Ashgate, p. 172.

Dodoo, C., \& Kuster, R. (1977), 'The road to Lomé', in Alting von Geusau, Frans. M. A. 'The Lomé Convention and a new international economic order' (p. 247), Leyden, A.W. Sijthoff International Publishing Company B.V.

Drieghe, L., (2009), 'revisiting the foundations of 30 years EU trade policy towards the ACP countries, an archival study on the Lomé Convention', Conference paper, EUSA conference 2009.

Duchene, F. (1973), 'The European Community and the Uncertainties of Interdependence', in M. Kohnstamm and W. Hager (eds), A Nation Writ Large? Foreign-Policy Problems before the EC, London, Macmillan.

-- (1972), 'Europe's Role in World Peace', in R. Mayne (ed.), Europe Tomorrow: Sixteen Europeans Look Ahead, London, Fontana.

Frey-Wouters, E., (1980), The European Community and the Third World, The Lomé Convention and its Impact, New York, Praeger Publishers.

Galtung, J. (1973), The European Community: A Superpower in the Making, Oslo, Universitetsforlaget.

Grilli, E. R., (1993), The European Community and the developing countries, Cambridge, Cambridge University Press,.

Holland, M., (2002), THe European Union and the Third World, Hampshire, Palgrave.

Hurt, S.R. (2003), 'Cooperation and Coercion?' The Cotonou Agreement between the EU and ACP States and the End of the Lome Convention', Third World Quarterly, 24:1, 161-76.

Hveem, Helge (1980), 'Scandinavia, the Like-Minded Countries, and the NIEO', In Laszlo, Ervin, Kurtzman, Joel (eds.), Western Europe and the New International Economic Order. Representative samples of European perspectives, New York, Pergamon Press, pp. 45-98.

Langan Mark, (2009), 'ACP-EU Normative Concessions from Stabex to Private Sector Development: Why the European Union's Moralised Pursuit of a 'Deep' Trade Agenda is nothing 'New' in ACP-EU Relations', Perspectives on European Politics and Society, Vol. 10, No. 3, pp. 416-440.

Lister, M., (1988), 'The European Community and the Developing World', Aldershot, Avebury. 
Orbie, J., (2007), 'The EU and the Commodity Debate: From Trade to Aid', Review of African Political Economy, 34:112, 297-311.

Orbie, J., 'A civilian power in the world? Instruments and objectives in European Union external policies', in J. Orbie (ed.) Europe's Global Role. External Policies of the European Union, Aldershot, Ashgate, 2008, pp. 1-34.

Pass, A te, Lomé en de praktijk. In: Kellerman, A.E. (ed.), 'De rol van de Europese Gemeenschappen in een nieuwe internationale economische orde'. 's Gravenhage, Asser Instituut Colloquium Europees Recht, Twaalfde Zitting, pp. 20-3.

Ravenhill, J., (1985), 'Collective Clientelism, the Lomé Convention and North-South Relations, New York, Columbia, Columbia University Press, p. 389.

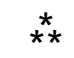

\begin{abstract}
This article examines the dynamics leading to the first Lomé Convention between the EC and the former colonies of its member states. In 1975 the EC and the ACP (African, Caribbean and Pacific) countries managed to conclude a comprehensive trade and development agreement, despite the period of eursclerosis and economic crisis. This article aims to explain this apparent paradox. First, we examine why Lomé has been perceived as a revolutionary agreement. In this respect four features of the agreement are elaborated: (1) its broad geographical reach, (2) its wide scope, (3) the development friendly nature of its trade regime, and (4) the EC's commitment to an equal partnership. Subsequently, we analyze the EC's motives to include these distinguishing features in the Convention. Based on a research in the EU records and some private collections, this study comes to the conclusion that this 'revolutionary' agreement was not the result of ambitious ideas about development, but stemmed from historical relations and practical consideration. Lomé I was to a large extent the continuation of previous policies by France and the United Kingdom towards their former colonies, and these two EC member states have largely shaped the content and nature of the agreement through intergovernmental bargaining. However, in times of eurosclerosis it might be useful to affirm Europe as an ambitious international actor as a response to the internal legitimacy crisis.
\end{abstract}

\title{
Résumé
}

Cet article examine les dynamiques menant à la première Convention de Lomé conclue entre la Communauté européenne (CE) et les anciennes colonies de ses États membres. En 1975, la CE et les pays dits ACP (pays d'Afrique, des Caraïbes et du Pacifique) arrivent à conclure un accord exhaustif de coopération commerciale et de développement, en dépit de l'eurosclérose et de la crise économique vécues à ce moment. Cet article vise à expliquer ce paradoxe apparent. En premier lieu nous examinons pourquoi Lomé a été perçu comme un accord révolutionnaire. À cette fin, nous élaborons quatre caractéristiques de l'accord: (1) sa large étendue géographique, (2) son envergure importante, (3) le développement de son régime commercial et (4) l'engagement de la part de la CE de forger un partenariat à part égale. Ensuite, nous analysons les raisons de la CE d'inclure ces caractéristiques distinctes dans la Convention. Basée sur une recherche dans les archives de l'UE et dans quelques collections privées, cette étude aboutit à la conclusion que cet accord "révolutionnaire" ne résulte pas d'idées ambitieuses au sujet de développement, sinon qu'il provient de relations historiques et de considérations pratiques. En majeure partie, Lomé I représente la continuité des politiques antérieures de la France et du Royaume-Uni vis-à-vis de leurs anciennes colonies et ce sont justement ces deux États membres de la CE qui contribuent largement à façonner le contenu et la nature de l'accord à travers des négociations intergouvernementales. Quoi qu'il en soit, en époque d'eurosclérose, il paraît utile d'affirmer la position de l'Europe en tant qu'acteur international ambitieux comme réponse à la crise interne de légitimité. 